\section{More to come but who pays?}

\section{Washington}

THE National Science Foundation (NSF) last week renewed its commitment to four of five existing supercomputer centres by extending the cooperative agreements with them through the 1995 fiscal year. But the next six years will be crucial ones for the centres, as they gradually end their role as prototype facilities for highperformance computing and become part of the US scientific infrastructure.

Supercomputer centres, and enhanced access to them via new, high-speed networks such as NSFNet, have changed the profile of computational science in the United States. NSF's commitment to supercomputer centres began in 1985 fiscal year. The four centres whose grants were renewed are at the University of Illinois at Urbana-Champaign, the University of California at San Diego, the University of Pittsburgh-Carnegie Mellon University and Cornell University.

Approval would, in all likelihood, have also come to the John von Neumann Center near Princeton, New Jersey, but last month Control Data Corporation announced it was discontinuing its ETA line of supercomputer. The Princeton centre uses ETA computers, and its future expansion plans included the next generation of these, so the centre is now scrambling to find alternatives. A decision on renewal has been deferred until later this year.

Although it is NSF's intention to increase funding levels from an average of $\$ 10$ million per centre to $\$ 14$ million, any increase will be contingent on how Congress deals with the Bush administration's NSF budget proposal.

While the centre's directors anxiously await the news about how much they will receive in next year's budget, of greater concern to them is a proposal intended to start the following year that would alter dramatically the way the researchers are allocated time at the centres.

Thomas Weber, director of the division of advanced scientific computing at NSF, says the agency is thinking about instituting a "green stamp" scheme for time on supercomputers at NSF centres.

Under the plan, programme directors would be given an allocation of green stamps for grantees. These stamps could be redeemed to the centres for computing time.

Weber says this plan will give NSF control over how supercomputer time is allocated, and make certain that NSF programme directors know what their grantees are doing. He adds that this will eliminate one stage of the review process, as at present researchers must compete for time at the centres.

But some worry that the real impact of the plan will be to drive people away from the centres. Doyle Knight, director of the von Neumann centre, says the greenstamp plan could lead to the same problem that struck university computing centres in the past decade. Knight says that after establishing the centres in the 1960 s, NSF reduced support, leaving universities to find independent support. For many centres this meant charging users real dollars for computing. But users, faced with a new expense and the old problem of sharing a central resource, started buying mini-computers that were less powerful but affordable and did not have to be shared.

Knight says this caused two problems. On the one hand, support for large powerful computers declined, and on the other computational scientists were forced to spend a significant portion of their time as computer operators. Larry Smarr, director of the University of Illinois centre, says it was as if astronomers traded a large optical telescope for one thousand pairs of binoculars. Although they might have the same total light-gathering capacity, says Smarr, the science is limited. NSF's de-

\section{London}

THE British government-owned National Engineering Laboratory (NEL) will be privatized several years from now, not within a few months as originally planned. After considering a report on the future of NEL from management consultants Touche Ross, the government announced last week that the laboratory would be allowed five to seven years in which to become profitable.

The chief scientist at the Department of Trade and Industry, Ron Coleman, told staff at NEL that when the necessary legislation is in place the laboratory will be transferred from the civil service to the ownership of a limited company, called the National Technology Centre. Initially, all the shares will be held by the government.

Over several years, the laboratory would be expected to undergo some restructuring in order to function as a commercial enterprise, including losing 200 of the 600 staff. To make better use of the space available at the NEL site, a science and technology park should be created around it.

The NEL, a mechanical-engineering laboratory, has supported industry by the transfer of technology at low cost. The government now insists that industry should pay the full costs of the research and development. But staff fear that the cision to reduce support for university computer centres led to a supercomputer famine according to Smarr.

One goal of the green stamp programme - to spread support for supercomputing activities among the many NSF directorates whose grantees use supercomputing facilities - is a good one, says Smarr, but the green-stamp mechanism is the wrong one. "The stupid thing about green stamps is we have solved the allocation problem, not by money but by peer review." Each of the centres now has a peer-review committee to judge requests for what is now essentially free time on the computers.

Thomas Day, president of San Diego State University and vice-chairman of the National Science Board that approves NSF's plans, says the supercomputer issue is a crucial one for the country's science infrastructure. The centres reflect the paradox of NSF's role in US science - on the one hand to generate new ideas and new directions for science, and on the other to support existing programmes. Whether the board supports the greenstamp scheme, the tug from these two competing drives will require some form of compromise.

\title{
NEL privatization delayed
}

laboratory may not survive in the private sector.

A representative of the Institute of Professional Civil Servants at the NEL, Stephen Marshall, says that research alone cannot be profitable, and the few existing independent research organizations may have saturated the market. Transferring the NEL into the private sector will be "a momentous task" and there are no assurances that the government will provide any support if it fails, he says.

The advice of management consultants was requested last year after the first hurried attempt at privatization failed. Announcing the sale, the government called for bids for the NEL, valued at about £30 million, within six weeks; negotiations with a potential buyer were unsuccessful.

Privatization has been ruled out for the moment for the government's environmental research laboratory at Warren Spring. It is to be given the status of an independent 'agency', which means loosening its ties to the DTI. The laboratory is expected to increase its income from private contractors and to compete for research contracts with government. The laboratory employs 300 staff and costs $£ 10$ million a year, more than two-thirds coming from government at present.

Christine McGourty 